\title{
Sevim Ak’ın Öykülerinin Duyarlık Eğitimi Açısından İncelenmesi
}

\author{
Esra KARAKUŞ TAYŞI*
}

Öz

Çocuk edebiyatı, bireye yaşamı tanıma ve anlamlandırma yolculuğunda çocukluğun ilk dönemlerinden yetişkinliğe kadar eşlik eden önemli bir alandır. Çocuğun bilişsel gelişimine, dil gelişimine, toplumsal gelişimine, yaşamı sanatsal açıdan algılama ve anlamlandırmasına katkısı yadsınamaz derecede büyüktür. Ancak önemli olan çocuk edebiyatının bireye sağladığı bu katkıların sayısal olarak fazlalığı değil niteliğidir. Nitelikli çocuk edebiyatı eserinin ayırt edici yönlerinden biri de bireyin yaşama karşı duyarlık gösterebilme becerisine katkı sağlamasıdır. Bireyin kendi hayatının ve ait olduğu dünyanın dışından durumlarla da ilgilenebilmesi ve bu durumları umursaması olarak değerlendirilen duyarlık, geliştirilmesi zorlu ve köklü çabalara dayanan bir süreç istemektedir. Sürecin etkililiğini artırmak için de çocukların erken dönemden itibaren nitelikli çocuk kitaplarıyla buluşturulması gerekir. Çalışmada, Sevim Ak'ın üç ayrı çocuk kitabı duyarlık eğitimi açısından incelenmiştir. Çalışmada temel nitel araştırma deseni kullanılmış, veriler doküman incelemesiyle elde edilmiştir. Duyarlık konularının belirlenmesinde ve gruplandırılmasında Aslan'ın (2016) oluşturduğu kategori dikkate alınarak içerik analizi yapılmıştır. Belirlenen 29 duyarlık konusundan biri dışında hepsi farklı oranlarda öykülerde tespit edilmiştir. En sık geçen konular insan ve insanın mutluluğu ve dilsel açıdan duyarlıktır. Bunların yanında aile bireylerine, aşka-sevgiye, hayvanlara, yardımlaşmaya, doğaya, dürüst olmaya karşı duyarlık sıkça ele alınmıştır. Bu yönüyle Ak'ın öykülerinin çocukların insana ve çevresindeki her şeye duyarlık kazanmasında, değer vermesinde etkili olacağı söylenebilir.

Anahtar Kelimeler: Sevim Ak, çocuk edebiyatı, duyarlık, duyarlık eğitimi

* Dr. Öğr. Üye. Kütahya Dumlupınar Üniversitesi, Eğitim Fakültesi, Türkçe Eğitimi ABD, Türkiye.

Elmek: esra.karakus@dpu.edu.tr

https://orcid.org/0000-0002-4669-6686 


\title{
Analysis Of Stories Of Sevim Ak In Terms Of Sensitivity Education
}

\begin{abstract}
Children's literature is a field which accompanies the individual in the journey of recognizing and interpreting life from childhood to adulthood. Its contribution to the child's cognitive development, language development, social development, and understanding and interpreting life from artistic point of view is significantly great. However, the important thing is not the quantity of these contributions made by children's literature but the quality of it. One of the distinctive aspects of quality children's literature is that it makes contribution to the individual's ability of showing sensitivity to life. Considered as the interest of the individual for situations which are out of his/ her own life and environment, sensitivity requires a process based on efforts which are essential and hard to develop. In order to increase effectiveness of the process, children should be introduced quality children's books in their early ages. In this study, three different children's books of Sevim Ak were analysed in terms of sensitivity education. Basic qualitative research design was used in the study, and the data was acquired through document analysis. In order to specify and classify the topics of sensitivity, content analysis was carried out by considering the coding carried out by Aslan (2016). Apart from one topic among the specified 29 topics, all topics were detected in stories at different rates. The most frequent topics are human, happiness of human, and sensitivity in terms of language. In addition to this, sensitivity to family members, love-compassion, animals, helping each other, nature, and being honest is frequently mentioned. From this point of view, it can be stated that stories of Ak can be effective in the individual's acquisition of sensitivity to human and everything around him/her.
\end{abstract}

Keywords: Sevim Ak, children's literature, sensitivity, sensitivity education 


\section{Extended Summary}

Children's literature is a field in which the extension of responsibility is wider because apart from artistic concerns, child literature needs to be appropriate for the cognitive and affective situation of the category of the society which it appeals to. In other words, children's literature should not only make the individual gain an artistic point of view but also do it in such a way that the child can understand and interpret. It can be stated that it is the basic difficulty that distinguishes children's literature from adult literature.

Beginning from the childhood period, children should be introduced quality children's books which will enable them to have a rich imagination, to look from different perspectives, to get a critical point of view, and to create sensitivity towards everything in their lives. This study aims to analyse the books of Sevim Ak, who is one of the most preferred authors by teachers, parents, and children, within the context of sensitivity education.

In the literature, there is no study discussing children's books of Sevim Ak in terms of their ability to give sensitivity education. In this study, Sevim Ak's books called "Sakız Kızın Günleri, Uçurtmam Bulut Şimdi, Pembe Kuşa Ne Oldu?" were analysed in terms of sensitivity education.

Since this study aims to analyse 27 stories in three different books of Sevim Ak in terms of sensitivity education, basic qualitative research design was used in the study. These three books form the sample of this research.

In basic qualitative research, data can be collected through interview, observation or document analysis (Merriam, 2013). Data of this research was acquired through document analysis. Based on the category system, stories were read one by one for the analysis. Messages about sensitivity education were written under the specified category. Content analysis was used to analyse the data.

In the short story book called Sakız Kızın Günleri, it is observed that the topics which can make children sensitive are mentioned 375 times. Sensitivity issue was approached 19 times in Sakız ve Rüzgar Adam, 17 times in the story of Sakız ve Aytaşı, and 17 times in the story of Sakız ve Hafta. The most frequent topics mentioned are the ones that can create sensitivity to human and happiness of human 
(f:29), being honest (f:24), language (f:20), and nature (f:19). According to the table, these issues are mentioned in the story of "Sakız ve Rüzgâr Adam" most.

In the short story book called Uçurtmam Bulut Şimdi, "Dut Ağacının Korkusu" is the story that contains the topic of sensitivity (12) most. The frequency of the sensitivity topic is 166 times. Sensitivity to women is highlighted in 9 stories while sensitivity to human and happiness of human is highlighted in 8 stories. Apart from these, sensitivity to family members, love-compassion, animals and being honest is frequently mentioned.

In the short story book called Pembe Kuşa Ne Oldu?, sensitivity to human and happiness of human is a topic approached in all stories. Sensitivity to nature is discussed in 8 stories, sensitivity to human relations is discussed in 7 stories, sensitivity to art, friendship, and being hopeful is discussed in 6 stories, and sensitivity to love-compassion and professions is discussed in 5 stories. Repetition frequency of topics is 174 times. "Kum Kaleler" is the story that contains the topic of sensitivity most.

Within the scope of this study, 27 different children's stories in Sevim Ak's books were analysed within the context of qualities that quality children's literature works should have in terms of sensitivity education, and it was determined that these stories shall make children sensitive in many issues.

Apart from one topic among the specified 29 topics, all topics were detected in stories at different rates. From this perspective, it can be concluded that the analysed stories are high rich in terms of topics related to sensitivity. The individual can acquire specific amount of sensitivity and awareness in different topics through these stories. It was observed that the most mentioned issues in the analysed stories are topics which can make the individual sensitive to human and happiness of human, and to language. On the other hand, topics which can make the individual sensitive to peace were not observed.

It can be stated that stories of Ak can be effective in the individual's acquisition of sensitivity to human and everything around him/her. In addition to this, as a frequently mentioned topic in her stories, sensitivity to language is important in terms of enabling children to understand the richness in meaning in Turkish. Within this scope, preferring the books of Ak by parents and teachers would be highly beneficial for the development of child. 


\section{Giriş}

Edebiyat, insanın, günlük hayatında karşılaşabileceğinden daha fazla deneyime, sevince, acıya, mutluluğa, farklı bakış açılarına en açık, anlaş1lır ve kolay şekilde ulaşılabilecek bir sanat dalıdır. Sanat ve sanatçı insana başka hayatları sadece göstermekle kalmaz, insanı o hayatlara ait bambaşka duygu ve durumlarla tanıştırıp kaynaştırır. Kavcar (1999) toplumundakilerin özlemlerini, ihtiyaçlarını en iyi duyumsayan ve sezen kişiler olan sanatçıların, duyarlığı, düşünüşü ve yorumlayışı ile dikkat çektiğini ve diğer insanlardan ayrıldığını belirtir. Sever (2008) bu bağlamda edebiyatın da insanlara sanatçı duyarlığı ile kurgulanmış bir yaşam sunduğunu ve insanların yaşam ve insan gerçekliğine sanatçının penceresinden bakabilmeyi sağladığını ifade eder.

Edebiyat, yüzyıllardır sanat dalları içerisinde etki alanı en geniş olanıdır. Temel işlevlerinden biri, insanı eğitme, insanın duygularını geliştirme; duygu ve düşünce arasında sağl1klı bir denge kurmadır (Kavcar,1999). Edebiyat; insanın duygu, düşünce, hayallerinin sanatçının düş gücü ve diliyle birleşerek vücut bulmasıdır. Böylece kişinin yaşamı farklı insanlarla, yaşamlarla, farklı düşüncelerle zenginleşir. Bu dünyada birçok yönden birbiriyle farkl111k gösteren durumların olduğunu ve bunlara karşı saygı ve hoşgörü duygusu geliştirmesini fark ettirir. İnsan bildikçe, tanıdıkça, gördükçe ve anladıkça duyar11 hâle gelmeye başlar (Aslan, 2013). Edebiyat duyarlık geliştirme sürecinde etkili bir araçtır çünkü bireyi duyarlı kılabilmek didaktik değil duyuşsal ve sanatsal bir süreçtir.

Çocuk edebiyatı ise edebiyatın sorumluluk alanı geniş olanıdır çünkü çocuk yazını taşıdığı sanatsal kaygıların yanında hitap ettiği kesimin bilişsel ve duyuşsal durumuna uygun olma zorunluluğu da taşımaktadır. Yani çocuk edebiyatı bireye sanatsal bir bakış açısı kazandırmanın yanında bunu çocuğun anlayıp aynı zamanda anlamlandırabileceği şekilde yapmalıdır. Çocuk edebiyatını yetişkin edebiyatından ayıran en temel zorluğun da bu durum olduğu söylenebilir. 
Çocuk Edebiyatı ve Duyarlık: Çocuğun toplumsal ve evrensel değerleri içselleştirebilmesi, benimseyebilmesi ve özümseyebilmesi yani duyarlık yeteneğini kazanabilmesi için olayları duyularıyla da algılayabilme becerisi geliştirmesi gerekir. Bu noktada, amacı kişilerin duyularını devindirmek olan sanatsal uyaranlara gereksinim duyulur. Amaçları bir değer öğretimi olmamakla beraber bu uyaranlar çeşitli değerleri etkileyici biçimde işlediklerinden onlara karşı okurların duyarlı olmalarını sağlayabilirler (Aslan, 2013). Nitelikli çocuk edebiyatı duyarlık eğitiminde tam da bu noktada büyük önem taşımaktadır. Çünkü nitelikli çocuk edebiyatının da duyarlık eğitimi sürecinin de en temel en önemli ve ortak olan özelliği dikte etmekten, öğüt vermekten ve çocuksuluktan uzak olması gerekliliğidir. Çocuk edebiyatı eserinin nitelikli olarak kabul edilebilmesi ve duyarlık eğitimi sürecine katkı sağlayabilmesi için yazarın değeri içselleştirme ve yorumlama aşamasında çocuğa özgürlük alanı bırakmış olması şarttır. Bu özgürlük alanı sayesinde birey kazandırılmak istenen değere karş1 duyusal bakış açısı kazanabilecektir.

Şirin'in (1994) de belirttiği gibi çocuk edebiyat1, her şeyden önce edebiyattır (Akt. Sever, 2008). Çocuklara yönelik olması edebî yönünde azalma ya da değişim yaşamasını gerektirmez. Aksine bireyin hayal ve algılama gücünün en geniş olduğu bir gelişim dönemine hitap ettiği için, çocuk edebiyatında edebî ve yaratıcı yönün daha ağır basması gerekir. Erdal'a (2009) göre, çocuk edebiyat1, bireye güzel ve kaliteli vakit geçirtmeyi amaçlamasının yanında daha karmaşık ve uygulanması zor sorumluluklar da taşıyan bir alandır. Kitaplar, çocukluk döneminden itibaren etkili olmaya ve bireyin hayatına girmeye başlamaktadır. Dilidüzgün (2007) bu bağlamda çocuklara kitap seçerken dikkatli olmanın anne-baba ve öğretmenlerin zorunlu bir görevi olduğunu ifade eder çünkü çocuğun duyarlı bir düşünce yapısına sahip olmasının yolu nitelikli kitaplardan geçmektedir. Çocuğa verilmesi gereken pek çok olumlu duygu, davranış şekli ve toplumsal değer, duyarlık eğitimi kitaplar aracılığıyla daha etkili olarak verilebilir.

Duyarlık, güncel Türkçe Sözlük’te “duyarlı olma durumu, duygunluk, hassaslık” olarak tanımlanmıştır. Aslan’a (2013) göre duyarlık, bireyin kendi hayatının ve ait olduğu dünyanın dışından durumlarla da ilgilenebilmesi bu durumları umursaması, sezinlemesi ve değerlendirebilmesidir. Ayrıca bu uya- 
ranlara karşı açık ve uyanık olması, tepkide bulunması, başka insanların yaşadıklarından etkilenmesi bu durumları görmezden gelmemesi; diğer insanların yaşadığı duygu durumlarını duyumsayabilmesi ve empati yoluyla anlamaya çalışmasıdır.

Duyarlık kavramı içinde bulunduğumuz çağın getirdiği ben merkezli tutum sebebiyle gün geçtikçe daha da önem kazanmaktadır. Bu kavramın geliştirilmesi, zorlu ve köklü çabalara dayanan bir süreç istemektedir. Bu sürecin kalıcılığının sağlanabilmesi için de bireyi etkileyen uyaranları ilk çocukluk evresinden itibaren düzenlemek gerekmektedir. Bu uyaranlardan en önemlilerinden biri çocuk edebiyatı eserleridir. Binyazar'ın (1996) da üzerinde durduğu gibi koşullamalı, tekdüze, konusal güdüme dayalı metinlerle yetişmiş bireyler duyarlık eğitimi bir yana; tek yönlü, seçenek bilmez, hoşgörü anlayışından yoksun bir kişilik yapısı gösterirler.

Aslan (2013), estetik ve örtük bir duyarlık eğitimi sürecini şu şekilde özetler; okur kahramanla özdeşim kurarak kurgudaki olaylar karşısında heyecan, mutluluk, kaygı, üzüntü, korku gibi duyguları yaşayarak metnin anlam evrenine girer ve duyumsaması kolaylaşır. Yazarlar, bu değerlere duyarlı kılacak kurgular oluşturup duygu algılarını etkileyecek söz varlığı kullanmalılar. Bu sayede, haksızlıklar, yanlışlar, kötülükler üzerine okurlarını duygulandırarak bunlar üzerine düşünmelerini sağlarlar. Alamdar ve Süngü'ye (2017) göre duyarlık eğitiminde amaç, insancıl değerleri, çocuğun gelişim özellikleri ve yaşı dikkate alınarak oluşturulan bir kurguyla çocuğa sezdirmek ve çocukta o konu ile ilgili duyarlık oluşturmaktır.

Nitelikli çocuk edebiyatı eserlerinin duyarlık eğitimi açısından taşıması gereken bazı özellikler vardır. Bunların başında dil duyarlığı gelir. Yazar, çocuğun düzeyine uygun bir anlatımla dilin inceliklerini, gücünü sezdiren eserler oluşturmalıdır. Kitaplarda, olumsuz durum ve duygular olumluymuş gibi verilmemeli, çocuğa bunların olumsuzlukları hissettirilmeli, insancıl durum ve duygular verilmelidir. Çocuk okuduklarını yaşamla ilişkilendirebilmeli ve verilmek istenen iletiler örtük olarak ifade edilmelidir. Hastalık, ölüm, boşanma, savaş, göç etme gibi yaşamın gerçekleri olan kavramlar çocuğun bilişsel ve duyuşsal gelişimi dikkate alınarak aktarılmalıdır (Alamdar ve Süngü, 2017). Görüldüğü 
gibi çocuklarla buluşturulacak eserler birçok özelliği taşımalıdır çünkü sadece toplumun okuryazarlık oranının artırılması yeterli değildir; okuduklarından çıkarımlar yapan, düşünce süzgecinden geçirip sorgulayan, duyarlı bireyler yetiştirilmesi de gerekmektedir. Bu sürecin de başlangıcı elbette çocukluk dönemidir. Çocuk, küçük yaşlardan itibaren düşünme dünyasını zenginleştirecek, farklı çerçevelerden bakmayı öğretecek, eleştirel bakış açısı kazandıracak, yaşamındaki her şeye yönelik duyarlıklarını oluşmasını sağlayacak nitelikli çocuk kitaplarıyla buluşturulmalıdır. Bu çalışmada da öğretmenler, aileler ve çocuklar tarafından çok tercih edilen yazarlardan biri olan Sevim Ak'ın kitaplarının duyarlık eğitimi bağlamında incelenmesi amaçlanmıştır.

Ak kitaplarında, içsel çatışmalar, boşanma, fırsat eşitsizlikleri, ekonomik sorunlar gibi her çocuğun yaşayabileceği konulara değinmekte ve çocukların özdeşim kurabileceği özelliklere sahip karakterler aracılı̆̆ıyla bu konuları çocukların dünyasından ele almaktadır. Alanyazında Sevim Ak'ın çocuk kitaplarının duyarlık eğitimi kazandırması noktasında değerlendirilen bir çalışmaya rastlanmamıştır. Bunun yanında söz varlığı (Özdemir Mete, 2016; Aktaş, 2016; Aytan, 2016), çocuk edebiyatının temel ögeleri (Doğan, 2015), iletiler (Arpac1, 2006) ve eğitsel iletiler (Uzuner Yurt, 2013; Özdemir, 2008), ölüm olgusunu betimleme (Şen, 2016), çocuğa görelik (Karaca ve Temizyürek, 2017) açısından inceleyen çalışmalar mevcuttur. Sevim Ak'ın çocuk kitaplarının doğrudan incelenmesinin yanında çocuk kitaplarıyla ilgili farklı çerçevelerde değerlendirmelerin yapıldı ğ çalışmalarda da Ak'ın eserlerine yer verilmiş̧tir. Aslan (2006) Türk çocuk yazınında çocuk-yetişkin çatışmasının yer aldığı yapıtları incelediği çalışmasında Ak'ın "Vitrindeki Mavi Bahçıvan" ve "Yeni Moda Kuaför" adlı öykülerini de ele almıştır. İki öyküsünde de aynı özellik ve kişiliklere sahip anne modellerini eleştirmiştir. Aslan ve Güldenoğlu (2018) 2017 y1lında en çok satılan kitaplardan biri olan Ak'ın "Uçurtmam Bulut Şimdi” adlı öyküsünde çocuk haklarını ne düzeyde ve nasıl yansıttığını ortaya koydukları bir çalışma yapmışlardır ve öykünün korunma hakkı, yaşamsal haklar ile ilgili olumlu anlatımlara en fazla yer verenlerden biri olduğunu belirtmişlerdir.

$\mathrm{Bu}$ çalışmada ise eserleri farklı çerçevelerden araştırılan ve öğretmenlerin beğendiği çocuk edebiyatçılarından (Kan, 2011) biri olan Sevim Ak’ın, “Sakız 
Kızın Günleri, Uçurtmam Bulut Şimdi, Pembe Kuşa Ne Oldu? ” isimli kitaplarındaki öyküleri duyarlık eğitimi açısından incelenmiştir.

\section{Yöntem}

Araştırma Deseni: Bu araştırmada temel nitel araştırma deseni kullanılmıştır. Nitel araştırmaların hepsi anlamın nasıl kurulduğuyla insanların hayatlarını ve dünyalarını nasıl anlamlandırdıklarıyla ilgilidir. Temel nitel araştırmanın öncelikli amacı da bu anlamları açığa çıkarıp yorumlamaktır (Merriam, 2013). $\mathrm{Bu}$ desenin tercih edilme sebebi de Sevim Ak'1n öykülerinden elde edilen verilerin nitel bir yaklaşımla yorumlanıp değerlendirilmesini sağlamasıdır.

Örneklem: Sevim Ak’ın üç ayrı kitabındaki 27 ayrı öykünün iletilerinin duyarlık eğitimi açısından incelenmesinin amaçlandığ araştırmanın örneklemini oluşturmaktadır. Bu kitapları belirlemek için amaç11 örnekleme yöntemlerinden ölçüt örnekleme kullanılmıştır. Bu örneklemede önceden belirlenmiş bir dizi ölçütü karşılayan bütün durumların çalışılmasıdır. Ölçüt ve ölçütler araştırmacı tarafından oluşturulabilir veya önceden hazırlanmış bir ölçüt listesi tercih edilebilir (Yıldırım ve Şimşek, 2018). Araştırmada örneklem belirlenirken öğretmen ve öğrencilerden görüş alınmış ve Sevim Ak'ın en çok tercih edilen kitapları ölçüt alınarak onlardan üçü seçilmiştir. Araştırmada incelenen kitaplar ve yayınevleri Tablo 1'de verilmiştir:

Tablo 1. Araştırmada Kullanılan Kitaplar ve Yayınevleri

\begin{tabular}{|c|c|c|c|}
\hline $\begin{array}{c}\text { Sıra } \\
\text { No }\end{array}$ & Kitap Adı & Öykü Sayısı & Yayınevi \\
\hline 1 & Sakız Kızın Günleri & 3 & Can Yayınevi \\
\hline 2 & Uçurtmam Bulut Şimdi & 14 & Can Yayınevi \\
\hline 3 & Pembe Kuşa Ne Oldu? & 10 & Can Yayınevi \\
\hline
\end{tabular}

Verilerin Toplanması ve Analizi: Veriler, temel nitel araştırmada görüşme, gözlem ya da doküman analizi yoluyla toplanabilir (Merriam, 2013). Bu araştırmanın verileri doküman incelemesiyle elde edilmiştir. "Doküman incelemesi, araştırılması hedeflenen olgu veya olgular hakkında bilgi içeren yazılı materyallerin analizini kapsar" (Yıldırım ve Şimşek, 2018). Kitaplardaki öyküler, kategori sistemi esas alınarak analiz için tek tek okunmuştur. Duyarlık eğitimiyle ilgili 
iletiler belirlenen kategorilerin altına yazılmıştır. Verileri analiz etmek için içerik analizi kullanılmıştır. İçerik analizi, verilerin kodlanması, temaların bulunması, kodların ve temaların düzenlenmesi, bulguların tanımlanması ve yorumlanması olmak üzere dört aşamada gerçekleşir (Yıldırım ve Şimşek, 2018).

Araştırmacı, içerik analizinde alanyazında var olan bir kodlama sistemini kullanabilir. Eğer yoksa kendisi bir kodlama sistemi geliştirebilir veya var olan bir kodlama sistemine olabilecek kodları da ekleyerek ihtiyaç duyduğu verileri elde edebilir (Smith, 2000: Akt Özden ve Cavlazoğlu, 2015: 45). Bu çerçevede verilerin kategorize edilmesinde Aslan'ın (2013, 2016), Alamdar ve Süngü’nün (2017) çalışmaları dikkate alınmıştır. Bu çalışmalardaki duyarlıklara ek olarak araştırmacı tarafından da yeni kategori başlıkları eklenmiştir. Kategoriler şu şekildedir:

1. Dilsel duyarlik

2. İnsana, insan mutluluğuna duyarlık

3. Kadina duyarlık

4. Aşka-sevgiye duyarlık

5. Hayvanlara duyarlık

6. Aile bireylerine duyarlık

7. Barışa duyarlık

8. İyilik yapmaya duyarlık

9. Paylaşmaya duyarlık

10. Toplumsal huzura duyarlık

11. Yardımlaşmaya duyarlık

12. Emeğe ve çalışkanlığa duyarlık

13. Yoksul insanlara duyarlık

14. Hakka, hukuka, adalete duyarlık

15. Temel yaşam ihtiyaçlarına duyarlık

16. Bilime duyarlık

17. Sanata duyarlık

18. Doğaya duyarlık

19. Sağlı̆ga duyarlık

20. Kişiye özgü özelliklere duyarlık

21. Özgüvenli olmaya duyarlık 
22. Özgürlüğe duyarlık

23. Mesleklere karşı duyarlık

24. Dürüst olmaya karşı duyarlık

25. Kitap okumaya karşı duyarlık

26. Ölüme karşı duyarlık

27. Arkadaşlı̆ga-dostluğa karşı duyarlık

28. İnsan ilişkilerine karşı duyarlık

29. Umutlu olmaya karşı duyarlık

Duyarlık kodları tablolarda gösterilirken yukarıda verilen sayılar kullanılmıştır. Kitaplar, A, B ve C harfleriyle, kitapların içindeki öyküler de a, b ve c biçiminde ilgili kitabın temsil ettiği harfin küçük harfiyle gösterilmiştir. Öyküler araştırmacı dışında bir alan uzmanı tarafından da okunup belirlenen kategoriler karşılaştırılmış ve farklı tespitlerde ilgili bölümler tekrar okunarak görüş birliği sağlanmaya çalışılmıştır. Sonra da bulguların yazılması ve yorumlanmasına geçilmiştir.

Bulgular ve Yorum: Bu bölümde Sakız Kızın Günleri, Uçurtmam Bulut Şimdi, Pembe Kuşa Ne Oldu?, isimli kitaplarda yer alan 27 öyküdeki farklı duyarlıklar belirlenerek her kitap için ayrı ayrı tablolaştırılarak verilmiştir.

İncelenen kitapların her biri birbirleriyle karakterler açısından bağlantılı, olay örgüsü ve iletiler açısından bağımsız öyküler içermektedir. Bu öykülerin hepsinde farklı konularda duyarlıklar görülmektedir. Öykülerde tespit edilen bu duyarlıkların çocuğun anlam dünyasına uygun bir yapı içinde kurgulandığı söylenebilir.

Sakız Kızın Günleri, bireyin insana ve insan mutluluğuna, özgüvenli ve özgür olmaya, aile bireylerine ve de kadına karşı duyarlık kazanmasını sağlayacak nitelikte üç ayrı öyküyü içermektedir. Eserde yer alan duyarlık konuları ve bu konuların ne kadar sıklıkla geçtiği tablo 2'de verilmiştir. 
Esra KARAKUŞ TAYŞİ, Sevim Ak’ın Öykülerinin Duyarlılık Eğitimi Açısından İncelenmesi

Tablo 2. Sakız Kızın Günleri Adlı Kitaptaki Duyarlık Konularına Ait Bulgular

\begin{tabular}{|c|c|c|c|c|}
\hline $\begin{array}{l}\text { Öykü } \\
\text { Kodu }\end{array}$ & Öykü Adı & $\begin{array}{c}\text { Duyarlık } \\
\text { Kodu }\end{array}$ & $\begin{array}{c}\text { Tespit Edilen Duyarlıkların } \\
\text { Geçme Sıklığı }\end{array}$ & $\begin{array}{c}\text { Toplam Duyarlık } \\
\text { Sayıları/ } \\
\text { Geçme Sıklığı }\end{array}$ \\
\hline A. a. & $\begin{array}{l}\text { Sakız ve } \\
\text { Aytaşı }\end{array}$ & $\begin{array}{l}1 / 2 / 3 / 4 / \\
5 / 6 / 10 / 12 / \\
14 / 15 / 16 / \\
17 / 18 / 19 / \\
20 / 21 / 22\end{array}$ & $\begin{array}{c}\text { 1.(2)/ 2.(20)/3.(7)/4.(2)/ 6.(5)/ } \\
\begin{array}{c}10 .(2) / 12 .(3) / 14 .(3) / 15 .(6) / \\
16 .(9) / 17 .(5) / 19 .(2) / 20 .(7) / \\
\\
21 .(3) / 22 .(24)\end{array}\end{array}$ & $17 / 100$ \\
\hline A. b. & $\begin{array}{l}\text { Sakız ve } \\
\text { Rüzgâr } \\
\text { Adam }\end{array}$ & $\begin{array}{c}1 / 2 / 4 / 5 / 6 \\
/ 8 / 9 / 10 / 11 / \\
12 / 13 / 15 \\
/ 16 / 17 / 18 \\
/ 19 / 20 / 21 \\
/ 23\end{array}$ & $\begin{array}{l}\text { 1.(11)/ 2.(29)/ 4.(10)/ 5.(2)/ } \\
\text { 6.(9)/ 8.(13)/ 9.(9)/ 10.(4)/ } \\
\text { 11.(9)/ 12.(17)/13.(3)/15.(11)/ } \\
\text { 16.(6)/ 17.(3)/ 18.(19)/ 19.(4)/ } \\
\text { 20.(16)/ 21.(2)/ 23.(6) }\end{array}$ & $19 / 183$ \\
\hline A. c. & $\begin{array}{l}\text { Sakız ve } \\
\text { Haftanın } \\
\text { Öyküsü }\end{array}$ & $\begin{array}{l}1 / 2 / 5 / 6 / 8 / \\
9 / 11 / 12 / \\
14 / 16 / 17 / \\
18 / 20 / 21 / \\
23 / 24 / 25\end{array}$ & $\begin{array}{c}1 .(20) / 2 .(9) / 5 .(3) / 6 .(5) / 8 .(5) / \\
9 .(4) / 11 .(3) / 12 .(5) / 14 .(2) / \\
16 .(4) / 17 .(2) / 18 .(5) / 20 .(5) / \\
21 .(4) / 23 .(2) / 24 .(12) / 25 .(2)\end{array}$ & $17 / 92$ \\
\hline
\end{tabular}

Tablo 2'de Sakız Kızın Günleri adlı öykü kitabında çocukları duyarlı k1lacak konuların metin içinde 375 defa geçtiği görülmektedir. Sakız ve Rüzgâr Adam'da 19, Sakız ve Aytaşı Öyküsü'nde 17 ve Sakız ve Haftanın Öyküsü'nde de 17 duyarlık konusu ele alınmıştır. Öykülerde, en çok insana ve insan mutluluğuna (f: 58), dile (f: 33), kişiye özgü özelliklere (f: 28), doğaya (f: 24), özgürlüğe (f: 24) duyarlık geliştirebilecek konular ele alınmıştır. Tabloya göre bu konular en çok "Sakız ve Rüzgâr Adam” öyküsünde geçmektedir.

Uçurtmam Bulut Şimdi isimli ikinci kitapta insana ve insan mutluluğuna, kişiye özgü özelliklere ve insan ilişkilerine dair duyarlık kazandırabilecek nitelikte on dört ayrı öykü yer almaktadır. Kitaptaki duyarlık konuları ve geçme sıklı̆̆ 1 tablo 3 'te gösterilmiştir: 
Tablo 3. Uçurtmam Bulut Şimdi Adlı Kitaptaki Duyarlık Konularına Ait Bulgular

\begin{tabular}{|c|c|c|c|c|}
\hline $\begin{array}{l}\text { Öykü } \\
\text { Kodu }\end{array}$ & Öykü Ad1 & Duyarlık Kodu & $\begin{array}{c}\text { Tespit Edilen } \\
\text { Duyarlıkların } \\
\text { Geçme Sıklığı }\end{array}$ & $\begin{array}{c}\text { Toplam Duyarlık } \\
\text { Sayıları/Geçme } \\
\text { Sıklığı }\end{array}$ \\
\hline B. a. & $\begin{array}{l}\text { Uçurtmam } \\
\text { Bulut Şimdi }\end{array}$ & $\begin{array}{c}2 / 3 / 6 / 8 / 14 / \\
20 / 24\end{array}$ & $\begin{array}{c}\text { 2.(1)/3.(1)/ 6.(2)/ } \\
\text { 8.(1)/ 14.(1)/ 20.(1)/ } \\
\text { 24.(1) }\end{array}$ & $7 / 8$ \\
\hline B. b. & Satılık Kitap & $\begin{array}{c}2 / 3 / 12 / 18 / \\
23 / 24 / 25 / 27 / 28 /\end{array}$ & $\begin{array}{c}2 .(1) / 3 .(1) / 12 .(3) / \\
18 .(2) / 23 .(2) / 24 .(1) / \\
25 .(4) / 27 .(1) / 28 .(1)\end{array}$ & $9 / 16$ \\
\hline B. c. & Yağmur Bulutu & $2 / 3 / 6 / 12 / 17 / 28$ & $\begin{array}{c}2 .(2) / 3 .(1) / 6 .(2) / \\
12 .(1) / 17 .(1) / 28 .(1)\end{array}$ & $6 / 8$ \\
\hline B. d. & Pisipisi Otları & $\begin{array}{c}1 / 3 / 16 / 18 / 24 / \\
28\end{array}$ & $\begin{array}{l}1 .(1) / 3 .(1) / 16 .(1) / \\
18 .(2) / 24 .(1) / 28 .(3)\end{array}$ & $6 / 9$ \\
\hline B. e. & Elişi Kâğgtları & $3 / 6 / 17 / 18$ & $\begin{array}{c}3 .(1) / 6 .(1) / 17 .(2) / \\
18 .(2)\end{array}$ & $4 / 6$ \\
\hline B. f. & $\begin{array}{l}\text { Büyümek } \\
\text { İstiyorum }\end{array}$ & $\begin{array}{c}3 / 6 / 12 / 15 / \\
18 / 24 / 26 / 28\end{array}$ & $\begin{array}{c}\text { 3.(2)/6.(2)/ 12.(2)/ } \\
15 .(2) / 18 .(1) / 24 .(1) / \\
26 .(2) / 28 .(1)\end{array}$ & $8 / 13$ \\
\hline B. g. & Bir Buluş & $\begin{array}{c}1 / 2 / 6 / 11 / 16 / \\
18 / 19 / 23 / 27 / 28 /\end{array}$ & $\begin{array}{c}1 .(2) / 2 .(3) / 6 .(1) / 11 . \\
(1) / 16 .(1) / 18 .(1) / 19 . \\
(1) / 23 .(1) / 27 .(1) / 28 . \\
(1)\end{array}$ & $10 / 13$ \\
\hline B. h. & Bir Çı̆̆lık & $\begin{array}{c}2 / 12 / 14 / 20 / 21 / \\
23 / 28 / 29\end{array}$ & $\begin{array}{l}\text { 2.(1)/12.(1)/ 14.(2) } \\
/ 20 .(2) / 21 .(2) / 23 . \\
(1) / 28 .(1) / 29 .(1)\end{array}$ & 8/ 11 \\
\hline B. 1. & $\begin{array}{c}\text { Gözlerimi Geri } \\
\text { Verin }\end{array}$ & $\begin{array}{c}1 / 3 / 4 / 6 / 9 / 19 / \\
24\end{array}$ & $\begin{array}{c}\text { 1.(2)/3.(1)/4.(3)/ } \\
6 .(1) / 9 .(2) / 19 .(1) / \\
24 .(2)\end{array}$ & $7 / 12$ \\
\hline B. i. & $\begin{array}{l}\text { Zamanı Gel- } \\
\text { meden }\end{array}$ & $\begin{array}{c}1 / 2 / 5 / 6 / 8 / 9 / \\
11 / 12 / 18 / 24 / 28\end{array}$ & $\begin{array}{c}\text { 1.(1)/2.(2)/5.(1) } \\
/ 6 .(1) / 8 .(2) / 9 .(1) / 11 \text {. } \\
(1) / 12 .(1) / 18 .(3) / 24 \text {. } \\
(1) / 28 .(2)\end{array}$ & $11 / 16$ \\
\hline B. $\mathbf{j}$. & $\begin{array}{l}\text { Dut Ağacinın } \\
\text { Korkusu }\end{array}$ & $\begin{array}{c}1 / 2 / 5 / 6 / 10 / 11 / \\
16 / 17 / 18 / 19 / \\
24 / 28\end{array}$ & $\begin{array}{l}\text { 1.(1)/2.(1)/5.(1) } \\
/ 6 .(1) / 10 .(1) / 11 .(1) \\
/ 16 .(1) / 17 .(1) / 18 .(3) \\
/ 19 .(1) / 24 .(2) 28 .(1)\end{array}$ & $12 / 15$ \\
\hline
\end{tabular}




\begin{tabular}{|c|c|c|c|c|}
\hline B. $\mathrm{k}$. & $\begin{array}{c}\text { Herkesin Bir } \\
\text { Yıldızı mı Var? }\end{array}$ & $\begin{array}{c}1 / 3 / 8 / 12 / 14 / \\
15 / 20\end{array}$ & $\begin{array}{c}1 .(2) / 3 .(2) / 8 .(1) / \\
12 .(1) / 14 .(1) / 15 .(1) \\
/ 20 .(2)\end{array}$ & $7 / 10$ \\
\hline B. 1. & $\begin{array}{c}\text { Vitrindeki } \\
\text { Mavi Bahçıvan }\end{array}$ & $\begin{array}{c}2 / 3 / 4 / 9 / 12 / 15 / \\
20 / 21 / 28 / 29\end{array}$ & $\begin{array}{c}2 .(2) / 3 .(1) / 4 .(2) \\
/ 9 .(1) / 12 .(1) / 15 . \\
(1) / 20 .(2) / 21 .(2) / 28 . \\
(1) / 29 .(1)\end{array}$ & $10 / 14$ \\
\hline B. $\mathbf{m}$. & Öyle Bir Gün & $\begin{array}{c}1 / 4 / 5 / 8 / 9 / 11 / \\
12 / 20 / 21 / 23 / 24\end{array}$ & $\begin{array}{c}\text { 1.(1)/4.(1)/ 5.(1)/8. } \\
(2) / 9 .(2) / 11 .(3) / 12 \text {. } \\
(1) / 20 .(1) / 21 .(1) / \\
23 .(1) / 24 .(1)\end{array}$ & $11 / 15$ \\
\hline
\end{tabular}

Tabloya göre Dut Ağacının Korkusu en çok duyarlık (12) konusunu içeren öyküdür. Duyarlık konularının geçme sıklığı 166'dır. 9 öyküde kadına duyarlık, 8 öyküde insana ve insan mutluluğuna duyarlık konusuna vurgu yapılmıştır. Bunlar dışında doğaya (f: 12), insan ilişkilerine (f: 12), emeğe ve çalışkanlığa (f: 11), aile bireylerine (f: 9), dürüst olmaya (f: 9) karşı duyarlığa da sıklıkla yer verilmiştir.

Pembe Kuşa Ne Oldu? isimli üçüncü kitap, insana ve insan mutluluğuna, umutlu olmaya, sanata, insan ilişkilerine ve arkadaşlığa-dostluğa karşı duyarlık oluşturabilecek konularla kurgulanmış on ayrı öyküden oluşmaktadır. Tablo 4 'te öykülerdeki konular ve ele alınış sıklığına ait bilgiler verilmiştir.

Tablo 4. Pembe Kuşa Ne Oldu? Adlı Kitaptaki Duyarlık Konularına Ait Bulgular

\begin{tabular}{|c|c|c|c|c|}
\hline $\begin{array}{c}\text { Öykü } \\
\text { Kodu }\end{array}$ & Öykü Adı & $\begin{array}{c}\text { Duyarlık } \\
\text { Kodu }\end{array}$ & $\begin{array}{c}\text { Tespit Edilen } \\
\text { Duyarlıkların } \\
\text { Geçme Sıklı̆̆ı }\end{array}$ & $\begin{array}{c}\text { Toplam Duyar- } \\
\text { lık Sayıları/ } \\
\text { Geçme Sıklı̆̆ }\end{array}$ \\
\hline C. a. & $\begin{array}{c}\text { Pembe Kuşa Ne } \\
\text { Oldu? }\end{array}$ & $\begin{array}{c}1 / 2 / 3 / 4 / \\
5 / 17 / 18 / \\
27 / 28 / 29\end{array}$ & $\begin{array}{c}1 .(1) / 2 .(1) / 3 .(1) / 4 .(3) / \\
5 .(1) / 17 .(1) / 18 .(1) / \\
27 .(1) / 28 .(1) / 29 .(1)\end{array}$ & $10 / 12$ \\
\hline C. b. & Hep Aynı Şarkı & $\begin{array}{c}2 / 5 / 17 / \\
18 / 20 / 21 /\end{array}$ & $\begin{array}{c}2 .(4) / 5 .(2) / 17 .(5) / 18 .(2) / \\
20 .(1) / 21 .(2) / 23 .(1) /\end{array}$ & $9 / 20$ \\
\hline C. c. & Benim Adım Titi & $\begin{array}{c}2 / 4 / 23 / 29 \\
28\end{array}$ & $2 .(3) / 4 .(1) / 23 .(1) / 28 .(1)$ & $4 / 6$ \\
\hline C. d. & Eski Bir Çin & $2 / 3 / 4 / 23 /$ & $2 .(2) / 3 .(1) / 4 .(1) / 23 .(1) /$ & $7 / 8$ \\
\hline
\end{tabular}




\begin{tabular}{|c|c|c|c|c|}
\hline C. e. & $\begin{array}{l}\text { Kerpeten } \\
\text { Sokağı'nın } \\
\text { Derdi }\end{array}$ & $\begin{array}{l}1 / 2 / 5 / 10 / \\
17 / 18 / 19 / \\
24 / 27 / 28\end{array}$ & $\begin{array}{c}\text { 1.(1)/ 2.(1)/ 5.(2)/ 10.(1)/ } \\
\text { 17.(2)/ 18.(2)/ 19.(1)/ } \\
\text { 24.(1)/ 27.(1)/ 28.(1) }\end{array}$ & $10 / 13$ \\
\hline C. f. & $\begin{array}{l}\text { Mavi Ada'da Bir } \\
\text { Gün }\end{array}$ & $\begin{array}{c}2 / 3 / 5 / 17 / \\
18 / 27 / 28 / \\
29\end{array}$ & $\begin{array}{c}\text { 2.(2)/3.(2)/ 5.(5)/ 17.(1)/ } \\
18 .(2) / 27 .(1) / 28 .(2) / \\
29 .(1)\end{array}$ & $8 / 16$ \\
\hline C. g. & Kum Kaleler & $\begin{array}{l}1 / 2 / 3 / 4 / \\
5 / 11 / 17 / \\
18 / 20 / 21 / \\
23 / 27 / 28\end{array}$ & $\begin{array}{c}1 .(1) / 2 .(8) / 3 .(1) / 4 .(1) / \\
5 .(1) / 11 .(1) / 17 .(2) / \\
18 .(3) / 20 .(4) / 21 .(5) / \\
23 .(3) / 27 .(2) / 28 .(5)\end{array}$ & $13 / 37$ \\
\hline C. h. & Şakacı Güneş & $\begin{array}{c}2 / 5 / 12 / \\
18 / 29\end{array}$ & $\begin{array}{c}2 .(2) / 5 .(1) / 12 .(1) / 18 .(3) / \\
29 .(1)\end{array}$ & $5 / 8$ \\
\hline C. 1 . & Melodi Adası & $\begin{array}{c}2 / 5 / 10 / \\
17 / 18 / 22 / \\
24\end{array}$ & $\begin{array}{l}\text { 2.(1)/ 5.(1)/ 10.(1)/ 17.(4)/ } \\
\quad \text { 18.(1)/ 22.(1)/ 24. (1) }\end{array}$ & $7 / 10$ \\
\hline C. i. & Güneş Saçlı Kız & $\begin{array}{c}1 / 2 / 4 / 9 / \\
18 / 20 / 21 / \\
23 / 25 / 27 / \\
28 / 29\end{array}$ & $\begin{array}{c}\text { 1. (2)/ 2.(7)/ 4.(2)/ 9.(1)/ } \\
18 .(3) / 20 .(3) / 21 .(3) / \\
23 .(1) / 25 .(1) / 27 .(10) / \\
28 .(10) / 29 .(1)\end{array}$ & $12 / 44$ \\
\hline
\end{tabular}

Tablo 4'e göre insana ve insan mutluluğuna duyarlık bütün öykülerde ele al1nan konudur. 8 öyküde doğaya duyarlık, 7 öyküde insan ilişkilerine karşı duyarlık, 6 öyküde sanata, arkadaşlığa-dostluğa ve umutlu olmaya karşı duyarlık, 5 öyküde aşka-sevgiye ve mesleklere karşı duyarlık konuları işlenmiştir. Bunlar dışında öykülerde dile, kadına, kişiye özgü özelliklere duyarlık da mevcuttur. Konuların tekrar etme sıklığı 174'tür. En çok duyarlık konusunu içeren öykü de “Kum Kaleler” dir.

İncelenen öykülerde en sık tekrar eden konunun insana ve insan mutluluğuna duyarlık (f: 99), en az tekrar eden duyarlık konusunun da ölüm (f: 2) olduğu sonucuna ulaşılmıştır. Bunların dışında doğaya 53, dile 47, kişiye özgü özelliklere 40 , insan ilişkilerine 34 , sanata 29 , aile bireylerine 28 , aşka-sevgiye 26 , emeğe ve çalışkanlığa 26, özgürlüğe karşı duyarlı kılacak konuların 25 defa tekrar ettiği belirlenmiştir. Barışa karşı duyarlık kazandıracak konulara rastlanmamıştır. Tablo 5 'te analizler sonucunda belirlenen duyarlıklar ve bunlara ait alıntılardan örnekler sunulmuştur. Her alıntının yanında öykünün ve duyarlık konusunun kodu bulunmaktadir. 
Tablo 5. Belirlenen Duyarlıklarla İlgili Öykülerden Alıntı Yapılan Bazı Bölümler

\begin{tabular}{|c|c|}
\hline $\begin{array}{l}\text { Öykü ve Duyarlık } \\
\text { Kodu }\end{array}$ & Alıntılar \\
\hline A.a.6. & $\begin{array}{l}\text { "Ailenin en yaşlısı ne derse o ad konurmuş doğan } \\
\text { bebeklere."(s.9) }\end{array}$ \\
\hline A.b.23 & $\begin{array}{l}\text { "Bu yüzden söyledikleri hep aklımda kalıyor, hiç unutmuyorum. } \\
\text { Ah, keşke gazete dağıtıcısı değil de öğretmen olsaymış.” (s.61) }\end{array}$ \\
\hline A.c.1. & $\begin{array}{l}\text { "Sakız bu işin altından alnının akıyla çıkabilecek güçte miydi } \\
\text { ki? ”,; "Off işler şimdiden sarpa sarmış gözüküyordu."(s.89) }\end{array}$ \\
\hline B.a.2.,8. & $\begin{array}{l}\text { “Televizyonda iki kişi alçak sesle konuşuyor. Birinin yüzünde } \\
\text { bıçak yarası var, hiç gülmüyor. Kötü adamlar hep böyle olurlar, } \\
\text { filmin sonunda da mutlaka ölürler.” (s.10) }\end{array}$ \\
\hline B.b.24. & $\begin{array}{l}\text { "Artık olanları saklayamazdım. Her şeyi olduğu gibi anlattım." } \\
\text { (s.20) }\end{array}$ \\
\hline B.c.2. & $\begin{array}{l}\text { "Burnumu babaannemin elbisesinin koluna sildim sessizce. Yağ- } \\
\text { mur çocukların gözyaşları mı yoksa?” s.24 }\end{array}$ \\
\hline B.d.3.,18.,28. & $\begin{array}{l}\text { "Kaldırımlara kilimler serildi. Kilimlere önce evcilik oynayan } \\
\text { çocuklar yerleşti, sonra kadınlar el örgülerini alıp geldiler. Çay- } \\
\text { danlıklar ocaklara kondu, bahçeler sulandı. Toprak ve çiçek ko- } \\
\text { kuyordu hava.” (s.25) }\end{array}$ \\
\hline B.e.18. & $\begin{array}{l}\text { "Hafif bir rüzgâr esiyor. Ilık ve ıslak. Saçlarımız, elişi kâğıtları } \\
\text { kıpırdaşıyor. Deniz kokuyor rüzgâr. Anne, duyuyor musun? Deniz } \\
\text { kokusu geldi. Evet. Rüzgâr denizden esiyor. Denizden esen rüzgâr, } \\
\text { deniz kokusunu bize kadar taşıyabilir mi? Elbette. Denizin koku- } \\
\text { sunu, nemini, tuzunu bile taşır.(s.29) }\end{array}$ \\
\hline B.f.26 & $\begin{array}{l}\text { “Ölürsek ne olur? Büyüyemezsin. Her şey yerle bir olunca hepi- } \\
\text { miz ölürüz. Kentimiz de ölür. Güneş bir daha gelmez kentimize." } \\
\text { (s.36) }\end{array}$ \\
\hline B.g.18.19 & $\begin{array}{l}\text { "Geçenlerde ögretmenimiz hava kirliliğinden söz etti. Çevreyi } \\
\text { ve havayı kirletmeye devam edersek bizden sonra gelecek ku- } \\
\text { şaklar bazı bitkileri de hayvanları tanıyamayacaklarmış. Çünkü } \\
\text { kirlilik bitki ve hayvan türlerini yok ediyormuş. İnsanları da hasta } \\
\text { ediyormuş." (s.39) }\end{array}$ \\
\hline B.h.20.,21. & $\begin{array}{l}\text { "Öne geçtim. Boyumun kısa olduğunun ikide bir söylenmesine } \\
\text { kızıyordum..." (s.46) }\end{array}$ \\
\hline B. 1.4. & $\begin{array}{l}\text { "Anneme olan sevgim cebimdeki parayla ölçülemezdi zaten..." } \\
\text { (s.57) }\end{array}$ \\
\hline
\end{tabular}




\begin{tabular}{|c|c|}
\hline B. i.5.,9. & $\begin{array}{l}\text { “...Beni görünce iki balık salladı karşıdan. Heey! Al bakalım! } \\
\text { Kedilere ver de sevinsinler.”(s.59) }\end{array}$ \\
\hline B.j.16.,17. & $\begin{array}{l}\text { "Aaa! Olmaz öyle şey! Ă̆açlar bizim dilimizden anlamaz ki! Mi- } \\
\text { tolojik bir inanış bu. Mitolojiye göre her ağacın bir perisi vardır. } \\
\text { Peri mi? Nereden çıktı bu? Hani cinler periler hep uydurmaydı?” } \\
\text { (s.64) }\end{array}$ \\
\hline B.k.1. & $\begin{array}{l}\text { “... Bu da eski bir deyim. Yıldızı alçak demek, her şeyden çabuk } \\
\text { etkilenir demek. Kolay hastalanır, başına sık kaza gelir demek. } \\
\text { Sen de öyle değil misin?” (s.71) }\end{array}$ \\
\hline B.1.20.,21. & $\begin{array}{l}\text { "Pantolonu giyip geldim. Aynanın karşısında şöyle bir kendime } \\
\text { baktım. Nasıl da değişmiştim! Eski giysilerimin bu kadar berbat } \\
\text { olduğunu bilmiyordum. Bana hasta görünümü veriyorlarmış } \\
\text { meğerse.” (s. 74) }\end{array}$ \\
\hline B.m.23. & $\begin{array}{l}\text { "Sen de baba mesleğini mi devam ettireceksin? Baban şimdiden } \\
\text { seni çalıştırıyordur. Hayır. Ben hostes olacağım!" (s.82,83) }\end{array}$ \\
\hline C. a.17.,18. & $\begin{array}{l}\text { "Aaa! Ses gökyüzünden geliyor. Gökkuşağının olduğu yerden. Bir } \\
\text { piyano sesi bu. Evet, evet... Bulutların arkasında biri var. Piyano- } \\
\text { yu çalan o!” (s.8) }\end{array}$ \\
\hline C. b.23. & $\begin{array}{l}\text { “Balıkçılar sabırlıdır, üstelik ağlarını hep aynı şarkıyı söyleyerek } \\
\text { salarlar.” (s.18) }\end{array}$ \\
\hline C. c. 2 . & $\begin{array}{l}\text { “Titi çok sevinmişti. İçinden zıp zıp zıplamak geldi. Ama tuttu } \\
\text { kendini.” (s.28) }\end{array}$ \\
\hline C. d.29. & $\begin{array}{l}\text { “Titi, bir gün bu sırrın çözüleceğini biliyordu. İçine doğmuştu. } \\
\text { Bu yüzden, her sabah hiç aksatmadan antikacı dükkânının önün- } \\
\text { den geçiyor, vitrine merakla bakıyordu...” (s.33) }\end{array}$ \\
\hline C.e.10.,27.,28. & $\begin{array}{l}\text { “O günden sonra, Kerpeten Sokak'ın insanları birbirleriyle } \\
\text { görüşmeye başladılar. Bahçelerde oturdular, şarkılar söylediler, } \\
\text { yemekler yediler.” (s.43) }\end{array}$ \\
\hline C. f.3.,5. & $\begin{array}{l}\text { "Annesi çamaşır yıkıyor, denizkaplumbağası kavanozunda tembel } \\
\text { tembel uyukluyordu." (s.44) }\end{array}$ \\
\hline C. g.2. & $\begin{array}{l}\text { "Ertesi sabah, kumsala inmeyi önce istemedi .Ama ,deniz klyısı- } \\
\text { na dikilmiş kumdan surları görünce içi sevinçle doldu..." (s.52) }\end{array}$ \\
\hline C. h.29. & $\begin{array}{l}\text { “ Bu bir şey değil ... Ama biliyor musun, bir gün bu dünyada ger- } \\
\text { çekten eksik olan bir şeyi bulacağım.” (s.66,67) }\end{array}$ \\
\hline C. 1.17.,22. & $\begin{array}{l}\text { “Yoo... Mutluydular. İkili 'Fa'bacak bacak üstüne atmış, ne } \\
\text { güzel, diyordu. Bunca zaman, bir insanın ağzından çıkmayı bekle- } \\
\text { yerek nasıl dayanmışım?” (s.78,79) }\end{array}$ \\
\hline
\end{tabular}




\begin{tabular}{|l|l|}
\hline C. i.2.,18. & $\begin{array}{l}\text { "Sabah erkenden kırlara çıktı. Döndüğ̈̈̈nde çok sevinçliydi. } \\
\text { Sikıntıları toz olup dağılmıştı. Nasıl dağılmasın? Kırlarda yeni } \\
\text { açmış, taptaze gelincikler görmüştü...” (s.82) }\end{array}$ \\
\hline
\end{tabular}

\section{Sonuç}

Bu çalışma kapsamında Sevim Ak'ın Sakız Kızın Günleri, Uçurtmam Bulut Şimdi, Pembe Kuşa Ne Oldu?, isimli kitaplarındaki 27 ayrı çocuk öyküsü nitelikli çocuk edebiyatı eserlerinin duyarlık eğitimi açısından taşıması gereken özellikler bağlamında çözümlenmiştir. Çocuklar için yazılan kitaplarda çocuğa görelik ilkesinden hareket edilerek örtük olarak belirli iletiler aktarılmak istenmektedir. Sever'e (1998:2-3) göre çocuğun yazınsal metinlerle kurduğu iletişim, her şeyden önce bir duygu ve düşünce eğitimidir. Bu süreçle birlikte çocukta duyarlık oluşumu, zenginliği, kültürel bilinçlenme sağlanır çünkü insanoğlunun serüvenlerinin hepsi yazarın duyarlık alanına girip onun duygu, düşünce ve düş gücüyle beslenir ve okura aktarılır. Yazarın oluşturduğu dünyada, okura sunduğu anlam evreninde insanoğlunun gerçeği vardır. Sevim Ak'ın incelenen öyküleri de bu amaca uygun olarak kaleme alınmış ve duyarlıklar bir kurgu içinde verilmiştir.

Belirlenen 29 duyarlık konusundan biri dışında hepsi farklı oranlarda öykülerde tespit edilmiştir. Bu bağlamda incelenen öykülerin duyarlık konuları açısından oldukça zengin olduğu söylenebilir. Bu öyküler aracılığıyla bireylerde, belli bir oranda farklı konularda duyarlık kazandırılıp farkındalık oluşturulabilir.

İncelenen öykülerde, en çok değinilenlerin insan ve insanın mutluluğu ve dilsel açıdan duyarlı kılacak konular olduğu görülmüsşür. Bunun yanı sıra öykülerde barışa duyarlı kılacak konulara rastlanmamıştır. Bunun sebebi öykülerde ele alınan konulara uygun olmaması olabilir.

İnsan ve insan mutluluğuna, kadına ve aile bireylerine karşı duyarlı, özgüveni yüksek ve özgür bireyler olmayı sağlayabilecek üç öykünün yer aldığ1 Sakız Kızın Günleri adlı kitapta, karakterlerin büyükanne ve büyükbabalarıla yaşadıkları eğlenceli ve sevgi dolu anılarının bir çocuğun gözünden aktarılması konu edilmiştir. Kitaptaki ilk öyküde canı eğlenmek isteyen Sakız'ın insanların her dileğini yerine getiren aytaşı tozunu rastgele insanların saçlarına bırakması ile ortalık karışır. Öykünün sonunda insanların her istediğinin aynı anda ve çabala- 
madan gerçekleşmesinin doğuracağı sonuçlar çocuğa kurguya yedirilerek verilmiştir. Birçok konuya duyarlık kazandıracağı düşünülen bu öykülerle özellikle çocukta aile bağlarına, kadına ve toplumsal huzura karşı duyarlık oluşmasını sağlanabilir.

Uçurtmam Bulut Şimdi isimli kitapta insana ve insan mutluluğuna, insan ilişkilerine ve kişiye özgü özelliklere ilişkin duyarlık kazandırabilecek on dört öykü vardır. İlk çocukluk çağında yaşanan hayal kırıklıkları gibi olumsuz duygular, aile bireylerinin ve büyüklerin yaptığı bazı hatalar bir çocuğun anı dünyasindan çocuğun anlam evrenine uygun bir kurgu ile öğreticilikten uzak bir üslupla yansıtılmıştır. Kitaptaki öykülerin çoğunda kadına duyarlık, insana ve insan mutluluğuna duyarlık konusuna vurgu yapılmıştır. Bunların yanında emeğe ve çalışkanlığa, aile bireylerine, aşka-sevgiye, hayvanlara, yardımlaşmaya, doğaya, dürüst olmaya karşı duyarlığı da ele almıştır.

Pembe Kuşa Ne Oldu? isimli kitapta ise yine insana ve insan mutluluğuna, umutlu olmaya, sanata, insan ilişkilerine ve arkadaşlığa-dostluğa karşı duyarlık oluşturabilecek konularla kurgulanmış on öykü bulunmaktadır. Kimi öykülerin ana kahramanları diğer öyküde karşımıza yan karakterler olarak çıkmaktadır. Kitaptaki öykülerin hepsinde insana ve insan mutluluğuna duyarlık konusu işlenmiştir. Doğaya, sanata, arkadaşlığa-dostluğa, insan ilişkilerine duyarlık konuları da sıklıkla vurgulanmıştır.

Ak'ın eserlerinin duyarlık eğitimini açısından kapsamlı olmasının yanında çocuk kitaplarında olması gereken birçok unsuru da barındırdığ1 görülmüştür. Karaca ve Temizyürek (2017)'in çalışmalarının sonuçları da bunu destekler niteliktedir. Ak'ın öykülerini çocuğa görelik ilkeleri bağlamında incelediklerinde hepsinin bu ilkeleri sağladığını, öykülerdeki tema ve konu değerlendirmesinde Türkçe Dersi (1-8. Sınıflar) Öğretim Programı'ndaki temalarla uyum gösterdiğini ve yaşamın içerisindeki konuların çocuk gerçekçiliğini dikkate alarak verdiğini, karakterlerin çocuk okura model olacak devingen özellikler taşıdığını belirtmişlerdir. Uzuner Yurt (2013) da Ak'ın öykülerini eğitsel iletiler bağlamında ele almış ve öykülerde iletilerin olumlu yönde olduğu sonucuna ulaşmışlardır.

Ak’ın çocuklar için kaleme aldığı kitaplarıyla ilgili yapılan çalışmalara bakıldığında kitaplarında sadece tek başına duyarlık eğitimini vurgulamadığı di- 
ğer değerlerle birlikte birbirini destekleyerek bir bütün olarak ele aldığ görülmektedir. Bu yönüyle Ak'ın öykülerinin bireylerin insana ve çevresindeki her şeye duyarlık kazanmasında, değer vermesinde etkili olacağı söylenebilir. Aynı zamanda öykülerinde sıklıkla geçen dilsel duyarlık konuları da çocuğun Türkçenin anlam zenginliğini göstermesi açısından önemlidir. Bu bağlamda Ak'ın kitaplar1nın gerek aileler, gerekse öğretmenler tarafından tercih edilmesi çocuğun gelişimi açısından oldukça yararlı olacaktır. 


\section{Kaynakça}

Aktaş, E. (2016). Okuma Eğitimi Açısından Sevim Ak'ın Çocuk Öykülerinde Söz Varlığı. Millî Eğitim, Say1 210 Bahar, 539-562.

Alamdar, S. G. ve Süngü, A. (2017) Nazım Hikmet'in Sevdalı Bulut Adlı Kitabındaki Masalların Duyarlık Eğitimi Bağlamında İncelenmesi. T. Şimşek ve B. V. Yıldız (Haz.) IV. Uluslarası Çocuk ve Gençlik Edebiyatı Sempozyumu içinde (s.301-314).

Arpacı, Ö. (2006). Çocuk Kitaplarında İletiler ve İletilerin Aktarım Biçimi (Sevim Ak Örneği). Yüksek Lisans Tezi. Mersin Üniversitesi Sosyal Bilimler Enstitüsü, Mersin.

Aslan, C. (2006). Türk Çocuk Yazınında Çocuk-Yetişkin Çatışmasının Yer Aldığı Kimi Yapıtların İncelenmesi. Ankara Üniversitesi Eğitim Bilimleri Fakültesi Dergisi, 39 (2), 193-216.

Aslan, C. (2013). Duyarlık ve Düşünceyi Geliştirmede Çocuk/Gençlik Edebiyatı. Çoluk Çocuk Anne Baba Eğitimci Dergisi, (12), 29-32.

Aslan, C. (2016). Oğuz Tansel'in Derleyip Yazdığı Masalların Duyarlık Eğitimi Bağlamında İncelenmesi. S. Sever ve S. Karagül (Haz.) Uluslararası Türk Masal Dünyası ve Doğumunun Yüzüncü Yılında Ŏguz Tansel Sempozyumu içinde (s.131-152).Ankara Üniversitesi Çogem, Odtü, Ankara.

Aslan, C. ve Güldenoğlu, D. (2018). Prof. Dr. Emine Akyüz'e Armağan Akademisyenlikte 50 Yıl. Y. Karaman Kepenekci ve P. Taşkın (Ed.), Çok Satılan Çocuk Edebiyatı Kitaplarında Çocuk Hakları Üzerine Bir Çözümleme içinde (90-102). Ankara: PegemA.

Aytan, T. (2016). Türk Çocuk Edebiyatı Üzerine Bir Söz Varlığı Çalışması: Atasözleri. Millî Ĕgitim, S. 210, 425-445.

Binyazar, A. (1996). Anadili Kitaplarında Yazınsal Metinlerden Yararlanılarak Duyarlık Eğitimini Gerçekleştirme. (Ed. H. Coşkun, İ. Kaya, J. Kuglin). Türkiye ve Almanya'da İlköğretim Ders Kitapları. Türk Alman Kültür İşleri Kurulu Yayın Dizisi, No.11.

Dilidüzgün, S. (2007). Masallar ve Masalsı Türler, Z. Güneş (Ed.) İlköğretimde Çocuk Edebiyatı (ss. 93-124) Eskişehir: Anadolu Üniversitesi Yayını.

Doğan, Ç. (2015). Sevim Ak’ın Çocuk Kitaplarının Çocuk Edebiyatının Temel Ögeleri Yönünden İncelenmesi ve Türkçe Eğitimine Katkısı. Erciyes Üniversitesi Eğitim Bilimleri Enstitüsü Yüksek Lisans Tezi. Kayseri.

Erdal, K. (2009). Eğitim Değerleri Açısından Çocuk Kitapları. Akademik Baklş, 17, 1-18.

Kan, O. M. (2011). Türkçe Öğretmenlerinin Çocuk Edebiyatı İle Illgili Görüşleri Üzerine Nitel Bir Araştırma, 3. Ulusal Çocuk Ve Gençlik Edebiyatı Sempozyumu, 05- 07 Ekim 2011 Ankara, 109-118.

Karaca, G.; Temizyürek, F. (2017). Sevim Ak’ın Öykülerinin Çocuğa Görelik İlkesi Açısından 
İncelenmesi. Bartın Üniversitesi Ĕ̈itim Fakültesi Dergisi, 6(1), 177-195.

Kavcar, C. (1999). Edebiyat ve Eğitim. Ankara: Engin Yayınevi.

Merriam, S. B. (2013). Nitel Araştırma Desen ve Uygulama Iç̧in bir rehber. (Qualitataive Research Aguide to Desing and Implementation). (çev: Selahattin Turan), Ankara: Nobel Yayıncilik.

Özdemir Mete, Ö. (2016). Sevim Ak'ın çocuk edebiyatı romanlarının söz varlığı açısından çözümlenmesi. Ankara: Ankara Üniversitesi Eğitim Bilimleri Enstitüsü: Yayınlanmamış Yüksek Lisans Tezi.

Özdemir, G. (2008). Sevim Ak’ın Hikâye Ve Romanlarında Yer Alan Eğitsel İletiler. Çanakkale: Çanakkale Onsekiz Mart Üniversitesi Sosyal Bilimler Enstitüsü: Yayınlanmamış Yüksek Lisans Tezi.

Özden, M. \& Cavlazoğlu, B. (2015). İlköğretim Fen Dersi Öğretim Programlarında Bilimin Doğası: 2005 ve 2013 Programlarının incelenmesi. Eğitimde Nitel Araştırmalar Dergisi, 3 (2), 40-65.

Sever, S. (1998). Demokratik Kültür Bilinci Edinimi Sürecinde Dil ve Edebiyat Öğretimi. Yaşadikça Ĕgitim, S(56), s.2-6.

Sever, S. (2008). Çocuk ve Edebiyat. İzmir: Tudem Yayınları.

Şen, E. ( 2016). Çocuk Edebiyatında Bir Yaşam Gerçekliği Olarak Ölüm Olgusu Üzerine Bir İnceleme (Sevim Ak Örneği). Uluslararası Türk Kültür Coğrafyasında Sosyal Bilimler Dergisi (TURKSOSBILDER), 1 (1), 14-23.

Türkçe Sözlük, Erişim Adresi:

http://tdk.gov.tr/index.php?option=com_gts\&arama=gts\&guid=TDK. GTS.5c820a5fb13f33.14977493

Uzuner Yurt, S. (2013). Sevim Ak`ın Öykülerinin Eğitsel Değerinin İncelenmesi. Erzurum: Atatürk Üniversitesi Eğitim Bilimleri Enstitüsü: Yayınlanmamış Doktora Tezi.

Yıldırım, A. ve Şimşek H. (2018). Sosyal Bilimlerde Nitel Araştırma Yöntemleri. 11. Bask1, Ankara: Seçkin Yayınları. 